\title{
Vaginal progesteronbehandling i graviditet forebygger ikke for tidlig fødsel
}

\author{
I Norge er det anbefalt vaginal behandling med progesteron for å forebygge for tidlig fødsel. En nylig publisert \\ randomisert kontrollert studie viser ingen effekt av slik behandling. De norske anbefalingene for vaginal \\ behandling med progesteron i graviditet bør revurderes og oppdateres med de nye funnene.
}

\begin{abstract}
Vaginal behandling med progesteron i graviditet for å forebygge for tidlig fødsel er i Norge anbefalt til kvinner med tidligere spontan for tidlig fødsel (før svangerskapsuke 34) og til kvinner med kort livmorhalslengde $(<20 \mathrm{~mm}$ påvist ved ultralyd før svangerskapsuke 32) (1). I OPPTIMUM-studien (2) som nylig ble publisert i tidsskriftet The Lancet ble kvinner fra Storbritannia og Sverige med forhøyet risiko for for tidlig fødsel randomisert til enten daglig vaginal behandling med $200 \mathrm{mg}$ naturlig progesteron eller placebo mellom svangerskapsuke 22-24 og 34 (2). Sammenlignet med placebogruppen hadde kvinnene i behandlingsgruppen ikke redusert risiko for fødsel før svangerskapsuke 34 eller intrauterin fosterdød, og barna hadde ikke redusert risiko for neonatal sykelighet og død eller forskjell i kognitiv skår ved to års alder på Bayley-IIIskala for utvikling hos nyfødte og små barn.

I de ujusterte sekundæranalysene fant man redusert risiko for neonatal død (oddsratio (OR) 0,17 ) og hjerneskade i nyfødtperioden (OR 0,50) hos barna i behandlingsgruppen. Disse interessante effektene av progesteronbehandling i nyfødtperioden reflekteres ikke i død inntil to års alder, ettersom det var høyere forekomst i proge-

alder, hvilket betyr at det nå foreligger data utover nyfødtperioden. En bred gruppe av kvinner med forhøyet risiko for for tidlig fødsel er inkludert i OPPTIMUM-studien, noe som er særdeles viktig slik de gjeldende norske anbefalingene er utformet.

For første gang har man studert effekten av progesteron på en nordeuropeisk befolkning, hvilket også er av stor betydning for norske kvinner. Forekomsten av for tidlig fødsel i Norden er blant de laveste i verden og i tillegg er det tidligere vist at forekomsten av kort livmorhals er langt lavere hos oss enn det som er rapportert $i$ tidligere progesteronstudier (3-6).

\section{«l særdeleshet bør man vurdere å fjerne anbe- falingen om vaginal progesteronbehandling til kvinner med tidligere for tidlig fødsel»} sterongruppen, men ikke signifikant forskjell mellom gruppene (OR 1,28). Flere av de andre kombinerte sekundærutfallene som ble studert ved to års alder, som død eller moderat til alvorlig nevrologisk utviklingsforstyrrelse (OR 1,45) og bare moderat til alvorlig nevrologisk utviklingsforstyrrelse (OR 1,48), antydet også høyere forekomst i progesterongruppen. Man fant imidlertid signifikant forhøyet risiko for sykelighet i mage-tarm-kanalen (OR 2,67), respiratorisk sykelighet (OR 3,03) og nyresykdom (OR 3,65) hos barna i behandlingsgruppen, men forekomsten av disse utfallene var lav. Forfatterne konkluderte med at vaginal progesteronbehandling i graviditet ikke forebygger for tidlig fødsel og neonatal sykelighet og at man ikke sikkert kan påvise fordeler eller ulemper inntil to års alder hos barna. Effekten av progesteron på utfall hos barna er enten ikke-eksisterende eller svak.

\section{Norske retningslinjer bør revurderes}

Studien er den største som er gjennomført på området. Man fulgte barna til to års
Resultatene fra OPPTIMUM-studien indikerer at nye uavhengige metaanalyser med data på individnivå er nødvendig om vi skal kunne påvise undergrupper av kvinner der vaginal progesteronbehandling kan ha effekt på forebygging av for tidlig fødsel. I tillegg kreves det ytterligere studier for å avklare om progesteronbehandling i graviditet kan gi uheldige langtidseffekter for barnet. Jakten på effektive behandlinger som kan forebygge for tidlig fødsel og som kan gi bedre helse for barnet på lang sikt må fortsette. De norske anbefalingene for vaginal behandling med progesteron i graviditet bør revurderes og man bør ta inn disse nye funnene. I særdeleshet bør man vurdere å fjerne anbefalingen om vaginal progesteronbehandling til kvinner med tidligere for tidlig fødsel før uke 34. Det finnes ingen dokumentasjon som støtter denne anbefalingen.

\section{Nils-Halvdan Morken}

nils-halvdan.morken@uib.no

Bo Jacobsson
Nils-Halvdan Morken (f. 1969) er spesialist i fødselshjelp og kvinnesykdommer. Han er førsteamanuensis ved Klinisk institutt 2, Universitetet i Bergen og overlege ved Kvinneklinikken, Haukeland universitetssykehus.

Forfatter har fylt ut ICMJE-skjemaet og oppgir ingen interessekonflikter.

Bo Jacobsson (f. 1960) er spesialist i fødselshjelp og kvinnesykdommer. Han er professor ved Sahlgrenska Akademin, Göteborgs Universitet, overlege ved Avdelning för obstetrik och gynekologi, Kvinnokliniken, Sahlgrenska Universitetssjukhuset og forsker ved Avdeling for genetikk og bioinformatikk. Folkehelseinstituttet i Oslo.

Forfatter har fylt ut ICMJE-skjemaet og oppgir ingen interessekonflikter.

Litteratur

1. Veileder i fødselshjelp 2014. http://legeforeningen. no/Fagmed/Norsk-gynekologisk-forening/ Veiledere/Veileder-i-fodselshjelp-2014/Truendefor-tidlig-fodsel/ (19.4.2016)

2. Norman JE, Marlow N, Messow CM et al. Vaginal progesterone prophylaxis for preterm birth (the OPPTIMUM study): a multicentre, randomised, double-blind trial. Lancet 2016: S01406736(16)00350-0.

3. Fonseca EB, Celik E, Parra M et al. Progesterone and the risk of preterm birth among women with a short cervix. N Engl J Med 2007; 357: 462-9.

4. Hassan SS, Romero R, Vidyadhari D et al. Vaginal progesterone reduces the rate of preterm birth in women with a sonographic short cervix: a multicenter, randomized, double-blind, placebo-controlled trial. Ultrasound Obstet Gynecol 2011; 38: $18-31$.

5. Kuusela P, Jacobsson B, Söderlund M et al. Transvaginal sonographic evaluation of cervical length in the second trimester of asymptomatic singleton pregnancies, and the risk of preterm delivery. Acta Obstet Gynecol Scand 2015; 94: 598-607.

6. Taipale P. Hiilesmaa V. Sonographic measurement of uterine cervix at 18-22 weeks' gestation and the risk of preterm delivery. Obstet Gynecol 1998; 92: 902-7.

Mottatt 11.4. 2016, første revisjon innsendt 19.4. 2016, godkjent 19.4. 2016. Redaktør: Ketil Slagstad.

Publisert først på nett. 